\title{
Open Access Information Service for Researchers in Theology
}

\section{Marianne Dörr}

Tübingen University, Germany

marianne.doerr@uni-tuebingen.de, orcid.org/0000-0002-0315-8079

\begin{abstract}
Tübingen University Library offers a continuously improved next generation bibliographic database for theology and religious studies. The "Index theologicus" database is available worldwide in open access. It is funded by the Deutsche Forschungsgemeinschaft (German Research Foundation) in the funding program "specialised information services." This paper informs the reader about the background of the project and the steps the Library took in order to transform a legacy online content database system into one of the most important international bibliographies in theology without increasing the number of staff involved.
\end{abstract}

Key Words: Library; Open Access Bibliography; Theology; Collaboration

\section{Introduction}

Tübingen University (founded in 1477) has a very strong tradition in theology. There are two large faculties, a catholic and a protestant one with internationally renowned researchers. As a result the University Library has very good collections in theology. Furthermore the Library was funded by the German Research Foundation for about 60 years to allow comprehensive collection building at a research level in theology and making the literature available via interlibrary loan to German scholars irrespective of where they work. As a sort of add-on the Library had started in the 1970s a service of photocopied 
contents of the most important journals held by the library, the contents were sent by post to interested scholars. This service was later replaced by a database, which was first available on CD-ROM, later online. It proved to be an appreciated information service (Weisweiler, 2003). The database was started in 1975 and comprised the article records of about 600 regularly indexed journals. Some years ago, the German Research Association changed its funding strategy for the special collections. The new program is called "Specialised information services for research." The focus is no longer on collection building, but on developing and delivering information services required by the scholars of the specific discipline (Dörr, 2014).

As the article-database was already known and used intensively, the Library decided to focus its work on this service and implemented important changes. The concepts and steps to transform the legacy database into a comprehensive international research bibliography are given in more detail in the following sections.

\section{Strategies for a Comprehensive Open Access Database}

\subsection{New Concepts and New Technology}

The aim was to transform the Index Theologicus into one of the most important international theological bibliographic databases. This required a completely new concept of the database and the workflows. We also had to decide on a new technology as the existing database system did not meet current technological standards.

In the stand-alone legacy database, cataloguing and indexing was done by manually typing in the bibliographic data of the articles. As we wanted to increase the number of indexed journals from 550 to more than 1,000 and to integrate also monographs and further sources in order to create a comprehensive bibliographical instrument we had to find new and more effective workflows. There was no additional staff available for this transformation. We started thinking about all possible forms of cooperations which could be helpful.

Tübingen University is part of the regional cataloguing network "Südwestverbund" $(\mathrm{SWB})^{1}$ including other universities with important 
theological faculties as Heidelberg and Freiburg. The SWB database contains already the records of theological monographs of Tübingen and other universities and institutions, and the current acquisitions are continuously catalogued in the SWB. We therefore decided to use the SWB as a sort of data-hub and aggregator: The article records from the legacy database were migrated and ingested in the SWB database. Since then monographs AND articles are indexed in the SWB. Also records coming from other sources (see below) pass through this aggregator. From there the data are exported in the Marc 21 format for the new presentation and search environment. This new discovery system was built with VuFind. VuFind is developed and maintained by Villanova University's Falvey Memorial Library, and is based on the open source software Solr, PHP and MySQL. The data sorting from SWB still have to be enriched and treated in order to enable the search features we want to offer to the researchers. ${ }^{2}$

\subsection{Cooperation and Collaboration}

The use of the cataloguing database of the SüdWestverbund as a sort of aggregator or datahub facilitates the reuse of records and collaboration. When extending the former article database to a comprehensive bibliography, the records of theological monographs, not only from Tübingen University, but also from other libraries (Freiburg, Heidelberg, Leipzig and Special Libraries in Stuttgart) were selected for the integration in Index Theologicus.

After intensive negotiations the publishing houses de Gruyter and Brill — both publish quite a number of relevant theological journals - agreed to contribute the metadata of their journals. After an initial delivery of a big amount of records, new records are now regularly integrated in the database. The BibliotheksserviceZentrum (BSZ) as the provider of the SüdWestverbund had to check the quality and the format of the data and to program an ingest routine. The data comprise not only the mere bibliographical records, but also abstracts and keywords of the articles. As a large number of journals of de Gruyter are the subject of a German national license, part of the records offer links to the full text, accessible for every German user of the database. For users from other countries the direct access depends on the license of their library.

Collaboration in article indexing is also feasible via the SWB: Some libraries within Baden-Württemberg are indexing some theological journals that 
before were part of the Tübingen workload. Further cooperations have been successfully initiated. The theological faculty of Innsbruck in Austria, responsible for a well-known specialised database for biblical literature, is currently migrating their data in Index Theologicus. Two theological institutes of the Universities of Münster and Würzburg, both producer of databases in specialised fields of theology (Canon law and Augustine of Hippo), have decided to follow this example. They were partners in the most recent application for funding to cover the expenses for this transformation.

\subsection{Semi-Automated Workflows and Further Automation}

Collaboration and shared indexing of journals is one possibility to save capacities in order to augment the number of indexed journals. But new methods have been implemented as well. Technical details have been described by Faßnacht and Gebhard (2016) and by Kim and Zumstein (2016).

In disciplines of the humanities like theology there are still quite a number of journals published exclusively in print. The article metadata of these journals are no longer typed in, but scanned. We use software from ImageWare Components to produce structured metadata from the tables of contents. For every journal a special template has to be created which meets the specific layout. As collected editions (Festschrift, Congress publications) are an important publication format in theology, we are currently trying in a project with the developer company to adapt the software in order to handle with acceptable correction rates the more or less heterogenous tables of contents of these publications.

Not only electronic journals, but also an increasing number of print journals are offering their article metadata electronically on their websites. In order to grab these already digitally available metadata we are working with Zotero. For each journal a so-called Zotero translator is developed, which captures the metadata in a structured format. With a second translator, the metadata can be enriched with further data and exported in union catalogue format (SWB). We try to match automatically authors' names with unique IDs of the German Integrated Authority File (GND) in order to disambiguate researchers. Only the names without matches have to be treated manually and intellectually. The further automation of this process is part of the developments 
in the new funding period which started in January 2018. The semi-automated processes for metadata creation seem to meet the needs of a lot of bibliographical enterprises. Our colleagues have already been invited to present this processes at several institutions. This is probably due to the fact that the data quality offered by aggregators as for example CrossRef has proved to be very poor.

\section{The New Index Theologicus (See Figure 1)}

\subsection{Content}

When starting the transformation, the database contained about 500,000 records of articles. Index Theologicus comprises currently about 1.8 million records of theological literature (monographs and articles) mainly in German, English, French and other European languages. The number of records is increasing every year by about 15,000 records. The integration of the Innsbruck, the Münster and the Würzburg databases will increase the number of records (after deduplication) significantly.

Fig. 1: Screenshot of the homepage of index theology.

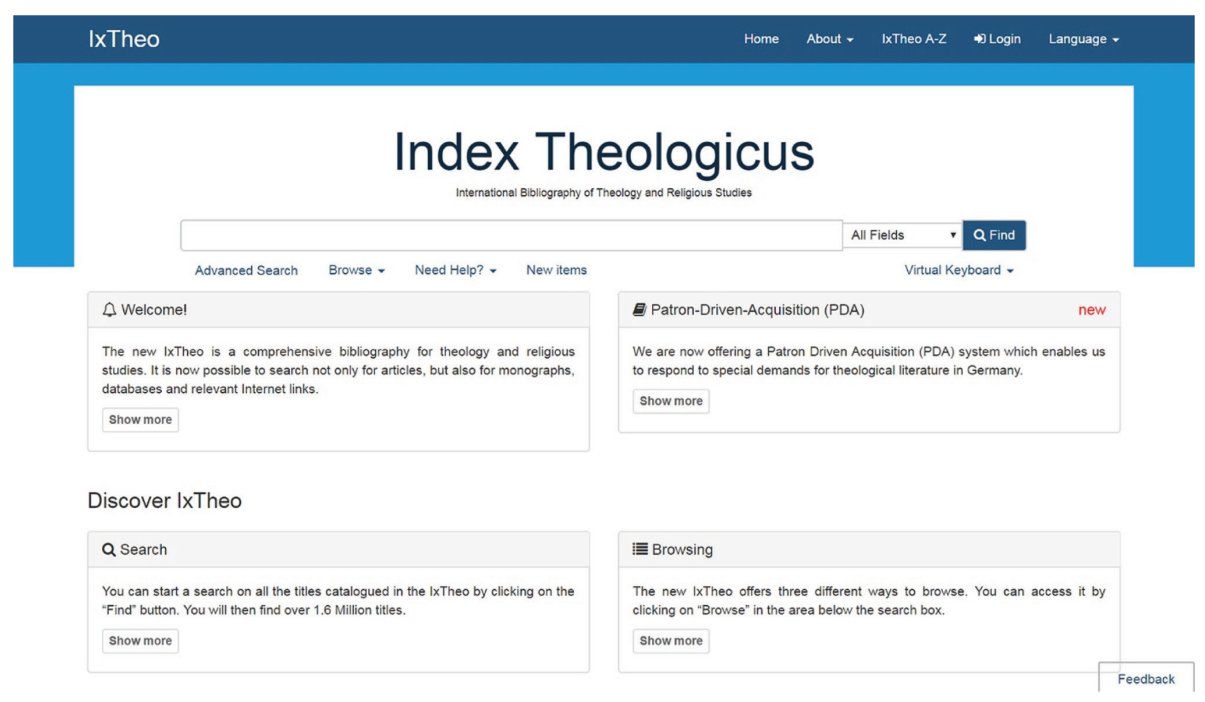




\subsection{Direct Access to Articles and Monographs}

The database does not only offer bibliographical records, but our aim is to give direct access to articles and facilitate the access to monographs. To do this the University Library pursues different strategies:

Green Open Access: About 130 acknowledged German researchers in theology have agreed that their articles - according to German copyright law - may be scanned and made accessible via Index Theologicus. The German copyright law gives authors the permission to publish articles one year after the first publication in a commercial journal on non-commercial platforms as institutional repositories. If no contract with a publishing house has been concluded for the first publication, the article may be used in the original layout. If a contract has been signed that prohibits further publication, this is nevertheless permitted, but in this case only the "accepted manuscript version" may be used.

Digitisation: A large project, which aims at the retrospective digitisation of theological journals, is currently in preparation. Some 60 editors want to cooperate. This project complements previous projects in which Tübingen University Library digitised theological journals from the 19th century and, with the agreement of the editors and publishers, one of the most important German review journals in theology (Theologische Literaturzeitung).

In order to facilitate the access to non-open access literature the database offers linkresolving and finding aid by using the DOIs. For monographs there is a special service offered by the "Hochschulbibliothekszentrum des Landes Nordrhein-Westfalen (hbz)" ${ }^{\prime \prime}$ which helps to locate the book in the local library catalogue of the user if the library has registered to this linkresolving service. Most German libraries and an increasing number of international libraries have done so, so far.

For journals subject to national licenses, there is a link to the online edition integrated in the record.

Interlibrary loan and document delivery are of course still important services that Tübingen University Library continues to offer. 


\subsection{Supporting Open Access Publishing}

Index Theologicus is an open access database and we try to support OA and to incite the academic community to publish in open access. We therefore have also installed Open Journals System (OJS) ${ }^{4}$ and offer hosting of open access journals. We started with one journal, edited by a professor of the theological faculty of Tübingen University. Currently 6 theological journals, not only German, but also from the Netherlands and Switzerland are preparing to migrate to OJS or to start publishing in OJS. In the humanities a lot of journals are still published by small publishing houses and edited by learned societies of faculties. Contact with the Tübingen staff often leads to consultation on existing journals. So several theological journals have complemented their articles by author keywords and abstracts, also in English, in order to strengthen the international visibility. And some journals are asking their authors to provide an ORCID number. In the long run this also facilitates the cataloguing process as the author identification process is already done.

\subsection{Search Features}

All databases offer simple and more sophisticated search options. As search of scientific articles about biblical scriptures is very important for scholars in biblical theology, we have implemented a special feature in the database. If a searcher types in a single bible passage as a search term he will - by the help of special algorithms - find also articles treating a larger range of bible passages, of which the typed-in passage is a part. This feature using the well known abbreviations of bible books is available not only in German, but also in the most important languages. ${ }^{5}$ Multilingualism is another important feature. The corpus of subject headings used in Index Theologicus had already been translated to English in the legacy system. In the meantime the subject headings have also been translated to Spanish, Portuguese, Italian, French (Roman languages are very important in Christian theology), Russian and Greek but also to Chinese as there is an increasing and in absolute figures a very high number of Christians in China.

In the current funding period we will pursue a project in order to improve the search in the database. Brill and a smaller, but renowned, local publishing house agreed to make all their fulltexts available to implement a sort of 
Google Books-like search: As the texts are under copyright they only serve to improve the search, the user will have access only to snippets of the text. This feature could be interesting for reuse of other bibliographic databases.

\section{Meeting the Needs of Researchers - Communication and Exchange}

The special information service in theology is constantly in dialogue with members of the German theological faculties and the main learned societies in theology. A representative academic board has been installed. Decisions as to, for instance, the inclusion of new journals in the database are made by the academic board.

The database attracts a lot of users. Compared to other disciplines the number of researchers in theology is relatively small. But there are about 7,000 visits per month and about 30,000 requests using about 4,000 specialised or unique search terms.

\section{Conclusion}

The new Index Theologicus is a comprehensive and well-used search instrument for researchers in Theology. The new concept, the new technology and the focus on automation on the one hand and cooperation on the other helped us to reach our aims. Therefore we consider the specialised information service theology as a best practice example for research oriented library services with a strong focus on open access and open data. We hope that further funding will be available in order to guarantee the free offer of Index Theologicus as a reliable instrument for researchers and scholars in theology.

\section{References}

Dörr, M. (2014). Vom Sondersammelgebiet zum Fachinformationsdienst - ein Praxisbericht. Zeitschrift für Bibliothekswesen und Bibliographie, 61(3), 130-137. https:// doi.org/10.3196/186429501461338. 
Faßnacht, M., \& Gebhard, W. (2016). Index Theologicus - neue Produktionsverfahren bei der Bibliographieerstellung. b.i.t.online, 19(6), 511-514. Retrieved May 5, 2017, from http://www.b-i-t-online.de/heft/2016-06-nachrichtenbeitrag-fassnacht.pdf.

Kim, T.C., \& Zumstein, P. (2016). Semiautomatische Katalogisierung und Normdatenverknüpfung mit Zotero im Index Theologicus. LIBREAS. Library Ideas, 29: Bibliographien, 47-56. https://doi.org/10.18452/9093.

Ruscheinski, J. (2018). Die IxTheo MARC pipeline. https:/ /github.com/ubtue/ ub tools/wiki/Die-IxTheo-MARC-Pipeline.

Weisweiler, H. (2003). Der Index Theologicus (IxTheo). Ein Fachinformationsdienst der Universitätsbibliothek Tübingen. In: B. Fiand, T. Hilberer, W. Lagler, \& U. Schapka (Eds.), "Fest-Platte": Beiträge aus der Universitätsbibliothek Tübingen für Berndt von Egidy anläßlich seines Ausscheidens aus dem aktiven Bibliotheksdienst im Juli 2003 (pp. 74-79). Tübingen: Universitätsbibliothek Tübingen. Retrieved June 29, 2018, from http://webdoc.sub.gwdg.de/ebook/aw/2003/egidy/dbt/volltexte/2003/826/ html/festplatte/rundgang/pdf/weisweiler3.pdf.

\section{Notes}

\section{${ }^{1}$ http://swb.bsz-bw.de/DB=2.1/START WELCOME.}

${ }^{2}$ The so-called "MARC pipeline was described by Ruscheinski (2018). It is surely not reusable as it is, but may inspire transfers to other databases.

${ }^{3}$ https://www.hbz-nrw.de/produkte/openurl-resolving/openurl-gateway.

${ }^{4}$ https://open-journals.uni-tuebingen.de/index.html.

${ }^{5}$ Example: Search for Romans 8,1 (have a look at the results): https://www.ixtheo. de/Search/Results?lookfor $=\mathrm{R} \% \mathrm{C} 3 \% \mathrm{~B} 6 \mathrm{~m}+8 \% 2 \mathrm{C} 1$ \&type $=$ BibleRangeSearch 